\title{
Enhancing Effect of Chloride Ions on the Autocatalytic Process of Ag(I) Reduction by Co(II) Complexes
}

\author{
Loreta Tamašauskaitè-Tamašiūnaitė *(D, Aldona Jagminienė, Ina Stankevičienè,

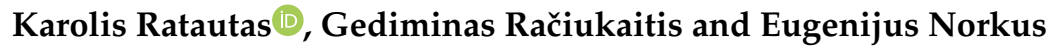 \\ Department of Catalysis, Center for Physical Sciences and Technology, Saulètekio Ave. 3, \\ LT-10257 Vilnius, Lithuania; aldona.jagminiene@ftmc.lt (A.J.); ina.stankeviciene@ftmc.lt (I.S.); \\ karolis.ratautas@ftmc.lt (K.R.); gediminas.raciukaitis@ftmc.lt (G.R.); eugenijus.norkus@ftmc.lt (E.N.) \\ * Correspondence: loreta.tamasauskaite@ftmc.lt
}

Received: 7 September 2020; Accepted: 12 October 2020; Published: 14 October 2020

check for updates

\begin{abstract}
In this work, the possibilities of increasing the rate of electroless silver plating without a rise in the concentration of reactants or elevation of temperature were studied. The effect of halide additive, namely chloride ions, on the rate of electroless silver deposition was investigated, using conventional chemical kinetics and electrochemical techniques. It was found that the deposition rate of electroless silver increased 2-3 times in the presence of $10-20 \mathrm{mM}$ of chlorides, preserving sufficient stability of the solution.
\end{abstract}

Keywords: electroless silver plating; Co(II) complexes; chloride ions

\section{Introduction}

Chemical deposition of silver layers (silver mirror formation) is the oldest known electroless plating process, but nowadays, the deposition of electroless silver is less effective and convenient compared to the electroless nickel or copper plating. Many reducers can be used for obtaining metallic silver from $\mathrm{Ag}(\mathrm{I})$ compounds, but generally, it is not so easy to get compact silver coatings due to the plenteous reduction of $\mathrm{Ag}(\mathrm{I})$ in the solution bulk. Unstable $\mathrm{Ag}(\mathrm{I})$-ammonia $\left(\mathrm{NH}_{3}\right)$ complex solutions with glucose, tartrate, formaldehyde, etc. have been used as reducing agents in plating for many years. The thickness of the coatings obtained from such solutions is not large and typically less than $1 \mu \mathrm{m}[1,2]$.

More effective electroless silver plating solutions have been developed using Ag(I)-cyanide complex and amine boranes [3] or hydrazine [4] as reducing agents. At $40-50{ }^{\circ} \mathrm{C}$, the deposition rate can reach $4 \mu \mathrm{m} \mathrm{h}^{-1}$, and in the presence of stabilizers, these solutions are sufficiently stable $[1,4,5]$.

It has been reported that $\mathrm{Co}(\mathrm{II})$ complexes with $\mathrm{NH}_{3}$ can be applied as $\mathrm{Ag}(\mathrm{I})$ reducers [6-8]. Under some conditions, there is a significant predomination of the deposition of silver on the surface to be plated compared with that formed in the solution bulk. Silver plating systems of high stability are obtained, even in the absence of stabilizing additives, plating rate being as high as $1-3 \mu \mathrm{m} \mathrm{h} \mathrm{h}^{-1}$. The reducing agent $\mathrm{Co}$ (II) can be regenerated: its oxidation product, $\mathrm{Co}$ (III) species, is reducible by both chemical and electrochemical means. Thermodynamic and kinetic analysis has shown [8-14] that the rate of the overall process mostly depends on the amount of free $\mathrm{NH}_{3}$ concentration, which is mainly determined by the total concentration of ammonium species $\left(\mathrm{NH}_{3}+\mathrm{NH}_{4}^{+}\right)$and the solution $\mathrm{pH}$. The influence of all main factors: solution $\mathrm{pH}$, temperature, concentrations of $\mathrm{Ag}(\mathrm{I}), \mathrm{Co}(\mathrm{II})$, and ammonium species, on the Ag deposition rate is determined.

It is worth knowing that according to Ref. [8], the electroless silver plating solutions are stable at a temperature of $50{ }^{\circ} \mathrm{C}$, and the plating rate reaches ca. $3.2 \mu \mathrm{m} \mathrm{h}^{-1}$. Theoretical aspects of electroless silver plating using $\mathrm{Co}(\mathrm{II})-\mathrm{NH}_{3}$ complexes are discussed in Refs. $[9,11,12]$, showing that $\mathrm{Co}\left(\mathrm{NH}_{3}\right)_{5}{ }^{2+}$ 
and $\mathrm{Co}\left(\mathrm{NH}_{3}\right)_{6}{ }^{2+}$ complex species are involved in the electroless silver plating process. The reduction process is shown to proceed according to the stoichiometric Equation (1):

$$
\mathrm{Ag}\left(\mathrm{NH}_{3}\right)_{2}^{+}+\mathrm{Co}\left(\mathrm{NH}_{3}\right)_{\mathrm{n}}^{2+} \stackrel{\mathrm{Ag}}{\rightarrow} \mathrm{Ag}+\mathrm{Co}\left(\mathrm{NH}_{3}\right)_{6}^{3+}+(\mathrm{n}-4) \mathrm{NH}_{3}
$$

where $\mathrm{n}=5$ or 6 .

The detailed kinetic study of electroless silver plating using $\mathrm{Co}(\mathrm{II})-\mathrm{NH}_{3}$ complexes as a reducing agent is given in Refs. [10,11,13].

The silver layers obtained in the $\mathrm{Ag}(\mathrm{I})-\mathrm{Co}(\mathrm{II})-\mathrm{NH}_{3}$ system have a regular crystalline structure [15] with good anti-corrosion ability [16] and optical reflection characteristics [17].

Co(II) complexes with organic amines, e.g., 1,3-propylenediamine, can also be used as reducing agents in electroless silver plating solutions [18]; the plating process parameters are similar to those of the ammonia solutions.

At the high quality of silver coatings deposited by using an $\mathrm{Ag}(\mathrm{I})$-Co(II) system and the high stability of the plating solutions, the silver plating rate may be too low for some practical applications where a thicker layer of silver is required. Alongside the practical importance, an acceleration of electroless silver deposition from the Co(II)-type solutions is a more general problem of enhancing the selective surface reaction of metal ion reduction without a considerable change in the process rate in solution bulk. It is agreed that the overall process of electroless metal consists usually of at least two interdependent electrochemical reactions: the anodic oxidation of the reducer and the cathodic reduction of the metal ions, taking place on the same catalytic surface. In our case, the anodic partial reaction - the oxidation of $\mathrm{Co}(\mathrm{II})$ - is sensitive to the ligands forming $\mathrm{Co}(\mathrm{II})$ complexes. It has been documented that the replacement of $\mathrm{NH}_{3}$ in a $\mathrm{Co}(\mathrm{II})$ complex by ethylenediamine (En) increases the anodic oxidation rate by a factor of 10-40 [18]. But the application of Co(II)-En complex for the electroless silver deposition is limited because of its too high reducing activity, leading to the fast reduction of $\mathrm{Ag}(\mathrm{I})$ in the volume of solution.

The anodic oxidation of $\mathrm{Co}$ (II)-ethylenediamine complex compounds on copper has been shown to be accelerated by halide ions, even at low concentrations $[19,20]$. A similar effect could be expected for other processes involving $\mathrm{Co}$ (II)-amine complexes. Therefore, this work aimed at the investigation of chloride ion effect on the process of electroless silver plating using $\mathrm{Co}(\mathrm{II})-\mathrm{NH}_{3}$ complex compounds as a reducing agent in detail by electrochemical quartz crystal microgravimetry (EQCM), the method that was not used earlier when investigating electroless silver plating systems. The electrochemical partial reactions of this process were also investigated.

\section{Experimental}

\subsection{Solutions}

Electroless silver deposition solutions were prepared as follows: the mixture of $\left(\mathrm{NH}_{4}\right)_{2} \mathrm{SO}_{4}$ and $25 \% \mathrm{NH}_{3}$ solutions was added to the $\mathrm{AgNO}_{3}$ solution. The solution was deaerated with $\mathrm{Ar}$ for $15 \mathrm{~min}$. After that, the $\mathrm{CoSO}_{4}$ solution was added. The main electroless silver deposition solution contained (M): $\mathrm{AgNO}_{3}-0.04, \mathrm{CoSO}_{4}-0.10,\left(\mathrm{NH}_{4}^{+}+\mathrm{NH}_{3}\right)-4$ or 7 . The solution $\mathrm{pH}$ was regulated by changing the molar ratio of $\mathrm{NH}_{4}^{+}$and $\mathrm{NH}_{3}$ (Table 1). Analytical grade chemicals and ultra-pure water with a resistivity of $18.2 \mathrm{M} \Omega \mathrm{cm}^{-1}$ were used for preparing the solutions. 
Table 1. Composition of electroless silver-plating solutions.

\begin{tabular}{ccccc}
\hline \multicolumn{5}{c}{ Concentration, $\mathbf{M}$} \\
\hline $\mathbf{p H}$ & $\mathbf{A g N O}_{3}$ & $\mathbf{C o S O}_{\mathbf{4}}$ & $\mathbf{N H}_{\mathbf{3}}$ & $\mathbf{( N H}_{\mathbf{4}} \mathbf{2}_{\mathbf{2}} \mathbf{S O}_{\mathbf{4}}$ \\
\hline 8.75 & 0.04 & 0.10 & 0.50 & 1.75 \\
9.2 & 0.04 & 0.10 & 1.00 & 1.50 \\
10.2 & 0.04 & 0.10 & 2.50 & 0.75 \\
11.2 & 0.04 & 0.10 & 3.80 & 0.10 \\
11.5 & 0.04 & 0.10 & 6.00 & 0.50 \\
\hline
\end{tabular}

\subsection{Electroless Silver Deposition}

Silver coatings were deposited onto glass substrates with a geometric area of $7 \mathrm{~cm}^{2}$. At first, the glass substrates, degreased in an acidic $\mathrm{Cr}(\mathrm{VI})$ solution, were sensitized in a $2 \mathrm{~g} \mathrm{~L}^{-1} \mathrm{SnCl}_{2}$ solution for $5 \mathrm{~min}$, then rinsed with ultra-pure water and further activated in a $10 \mathrm{~g} \mathrm{~L}^{-1} \mathrm{AgNO}_{3}$ solution, followed by rinsing with ultra-pure water. After that, the activated substrates were immersed in the deaerated electroless silver plating solutions (Table 1) at a temperature of 20 or $50 \pm 1{ }^{\circ} \mathrm{C}$ for $30 \mathrm{~min}$. Moreover, the reaction vessel was closed, and all vessel volume was filled with the solution to prevent the oxidation of $\mathrm{Co}$ (II) ions by atmospheric oxygen. The bath loading in kinetic experiments was $7 \mathrm{dm}^{2} \mathrm{~L}^{-1}$.

\subsection{Silver Coatings Characterization}

The mass of the silver coating deposited on the glass substrate was determined by weighing, whereas the thickness of the one was calculated using the density of pure bulk silver. The atomic force microscope (AFM) TopoMetrix Explorer SPM (Veeco, Santa Clara, CA, USA) was used for the silver surface inspection.

\subsection{Determination of the Real Surface Area of the Ag Electrode}

The real silver coating surface $\left(S_{R}, \mathrm{~cm}^{2}\right)$ was determined using the underpotential deposition (UPD) of the lead $(\mathrm{Pb})$ monolayer on the Ag electrode surface, as described in [21]. Briefly, the measurements were carried out in a $0.1 \mathrm{M} \mathrm{NaOH}$ and $0.5 \mathrm{mM} \mathrm{Pb}\left(\mathrm{NO}_{3}\right)_{2}$ solution. At first, the silver oxide $\left(\mathrm{Ag}_{2} \mathrm{O}\right)$ was removed from the surface of the working Ag electrode (the same quartz crystal electrodes coated with silver, as described in Section 2.3, were used) by holding the potential at $-0.10 \mathrm{~V}$ for $5 \mathrm{~s}$. During a cyclic scanning of the potential in the range from 0 to $-0.57 \mathrm{~V}$ at a scan rate of $50 \mathrm{mV} \mathrm{s}^{-1}, \mathrm{a} \mathrm{Pb}$ monolayer was formed and dissolved. The typical cyclic voltammogram is presented in Figure 1. The charge $(Q, \mu C)$ used for the anodic dissolution of the $\mathrm{Pb}$ monolayer was calculated by integration of the potentiodynamic curve obtained in the range from -0.45 to $-0.2 \mathrm{~V}$ (Figure 1).

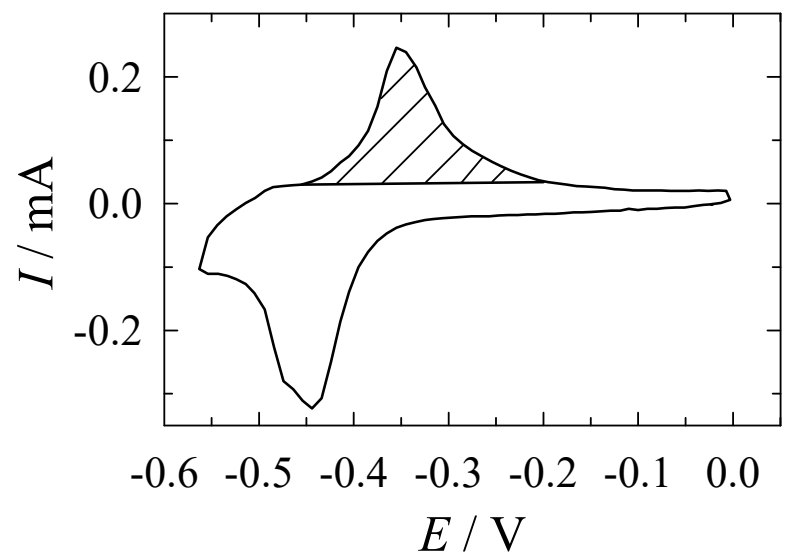

Figure 1. $\mathrm{Pb}$ underpotential deposition (UPD) on the electroless silver electrode. Solution composition (M): $\mathrm{Pb}\left(\mathrm{NO}_{3}\right)_{2}-0.5 \times 10^{-3}, 0.1 \mathrm{M} \mathrm{NaOH}$. Potential scan rate $50 \mathrm{mV} \mathrm{s}^{-1} ; 20^{\circ} \mathrm{C}$. 
The $S_{\mathrm{R}}$ of the Ag electrode was calculated using the charge of $\mathrm{Pb}$ monolayer $\left(\mathrm{QPb}_{\mathrm{Pb}}\right)$ necessary to form a monolayer on $1 \mathrm{~cm}^{2}$ of the electrode being equal to $280 \mu \mathrm{C} \mathrm{cm}^{-2}$ according to the Equation (2):

$$
S_{\mathrm{R}}=Q / Q_{\mathrm{Pb}}
$$

The roughness factor $R_{\mathrm{n}}$ was calculated according to Equation (3):

$$
R_{\mathrm{n}}=S_{\mathrm{R}} / S_{\mathrm{G}}
$$

where $S_{G}$ is the geometric area of silver coating.

The surface roughness was also calculated from the EQCM data. The deposited and dissolved $\mathrm{Pb}$ mass was obtained from the frequency change using the theoretical calibration constant $7.8 \mathrm{ng} \mathrm{cm}^{-2} \mathrm{~Hz}^{-1}$, and the surface area was calculated by using Pb monolayer mass $320 \mathrm{ng} \mathrm{cm}^{-2}$. The values of $S_{R}$ of silver coating calculated from the coulometric and EQCM data were in satisfactory agreement. The more detailed description of the determination of the Ag real surface area by these techniques is given elsewhere [21].

All measurements were repeated at least three times, and a mean value was calculated.

\subsection{Electrochemical and EQCM Measurements}

The home-built electrochemical quartz crystal microbalance (EQCM) system employed was the same as that in [20,22]. Briefly, a three-electrode electrochemical cell was used. A working electrode was a gold-coated AT-cut quartz crystal of $6 \mathrm{MHz}$ fundamental frequency (Intellemetrics Ltd., Paisley, UK) with a geometric area of $0.636 \mathrm{~cm}^{2}$, whereas an $\mathrm{Ag} / \mathrm{AgCl} / \mathrm{KCl}_{\text {sat }}$ electrode and a Pt-wire were used as a reference and a counter electrode, respectively. Cyclic voltammograms (CVs) were recorded from the open-circuit potential to the cathodic direction at a scan rate of $2 \mathrm{mV} \mathrm{s}^{-1}$. The values of the measured electrode potential, current, and frequency (with the stability of $\pm 0.5 \mathrm{~Hz}$ ) were transferred to the PC every $1.3 \mathrm{~s}$. The quartz crystal frequency change rate $(d f / d t)$ was found as a difference between two frequencies measurements per $1 \mathrm{~s}$ and was used in this work for the calculation of the anodic/cathodic Ag current. The calibration constant $140 \pm 10 \mathrm{~Hz} \mathrm{~s}^{-1} \mathrm{~mA}^{-1}$ was found in separate experiments in $\mathrm{Ag}(\mathrm{I})-\mathrm{NH}_{3}$ solutions. Moreover, this value was close to that calculated from Sauerbrey's [23] equation for the reduction of $\mathrm{Ag}(\mathrm{I})$ ions and corresponded to the sensitivity of EQCM used $7.98 \mathrm{~Hz} \mathrm{ng}^{-1}$ $\left(12.55 \mathrm{~Hz} \mathrm{ng} \mathrm{cm}^{-2}\right)$, whereas a theoretical value of the sensitivity is $7.8 \mathrm{~Hz} \mathrm{ng}^{-1}\left(12.26 \mathrm{~Hz} \mathrm{ng} \mathrm{cm}{ }^{-2}\right)$. $\mathrm{Ag}(\mathrm{I})$ reduction and $\mathrm{Ag}$ anodic dissolution currents were calculated by converting the $\mathrm{df} / \mathrm{dt}$ to the current equivalent using this calibration constant. Partial currents of the oxidation of Co(II) and reduction of $\mathrm{Co}(\mathrm{III})$ were determined as a difference between the measured net current and that of $\mathrm{Ag}$ reduction/dissolution derived from EQCM data. The electrode potential was quoted versus a standard hydrogen electrode (SHE).

Before the measurements, a silver coating was electrodeposited onto a gold-coated quartz crystal substrate mounted in the cell from the $0.5 \mathrm{M} \mathrm{AgNO}_{3}$ and $0.5 \mathrm{M} \mathrm{HNO}_{3}$ solution at a current density of $4.7 \mathrm{~mA} \mathrm{~cm}^{-2}$ for $2 \mathrm{~min}$.

The electroless silver coating was deposited onto the previously electroplated silver coating from an $\mathrm{Ag}(\mathrm{I})-\mathrm{Co}(\mathrm{II})-\mathrm{NH}_{3}$ solution for $5 \mathrm{~min}$. The solution composition (M) was: $\mathrm{Ag}_{2} \mathrm{SO}_{4}-5 \times 10^{-3}$; $\mathrm{CoSO}_{4}-0.1 ; \mathrm{NH}_{3}-4.0 ; \mathrm{pH} 10.9$. $\mathrm{KCl}$ additive concentration varied from 1 to $100 \mathrm{mM}$.

\section{Results and Discussion}

\subsection{Electrochemical and EQCM Measurements}

The kinetics of electroless silver deposition using the Co(II) complexes as reducing agents was investigated in detail. It was found that the addition of chlorides enhances $\mathrm{Ag}$ (I) reduction by $\mathrm{Co}(\mathrm{II})$ in $\mathrm{NH}_{3}$-containing solutions, as depicted in Figure 2. The accelerating effect of chloride ions is observed in a wide range of $\mathrm{NH}_{3}$ concentrations-in the entire practical $\mathrm{pH}$ range of electroless silver plating 
solutions of this type, beginning from $\mathrm{pH} 8.75\left(0.5 \mathrm{M} \mathrm{NH}_{3}\right)$ and concluding by the solution containing 3.8 $\mathrm{M} \mathrm{NH}_{3}, \mathrm{pH}$ 11.2. Moreover, the chloride effect is seen at the concentration as low as $1 \mathrm{mM}$, and the silver deposition rate increases most strongly with a rise in chloride concentration until ca. $10 \mathrm{mM}$. At upper chloride concentrations, the silver plating rate increases only a little, and the dependences of "plating rate to $\mathrm{Cl}^{-}$concentration" have a similar form in most cases, with some exception for the solution at $\mathrm{pH} 10.2$ (Figure 2).

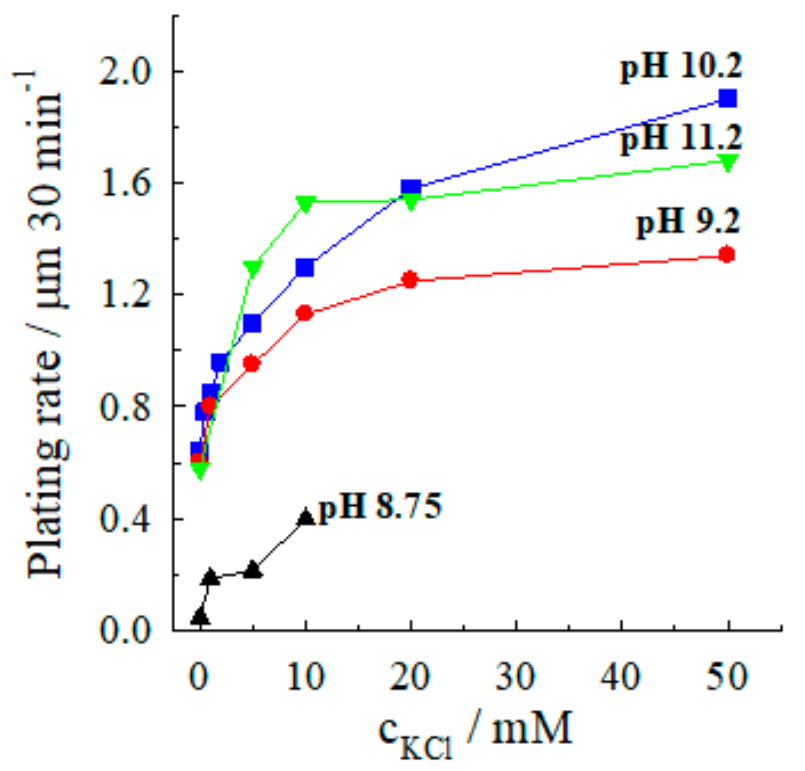

Figure 2. Dependence of the silver deposition rate on the chloride concentration at various $\mathrm{pH}$. Solution composition (M): $\mathrm{AgNO}_{3}-0.04, \mathrm{CoSO}_{4}-0.10 ;\left(\mathrm{NH}_{3}+\mathrm{NH}_{4}^{+}\right)-4 ; 20{ }^{\circ} \mathrm{C}$.

The acceleration of the autocatalytic silver deposition by chloride ions is relatively large: in the $\mathrm{pH}$ range 9.2-11.2, the addition of $10 \mathrm{mM} \mathrm{KCl}$ increases the plating rate from ca. 0.6 (chloride-free solution) to $1.2-1.5 \mu \mathrm{m} 30 \mathrm{~min}^{-1}$ (Figure 3), and at higher chloride concentrations, the plating rate reaches $1.8 \mu \mathrm{m}$ $30 \mathrm{~min}^{-1}$. So, the addition of $10 \mathrm{mM}$ chloride leads to an acceleration of electroless silver deposition by a factor 2-2.5, and at higher chloride concentrations (40-50 mM), a three-fold acceleration is achieved.

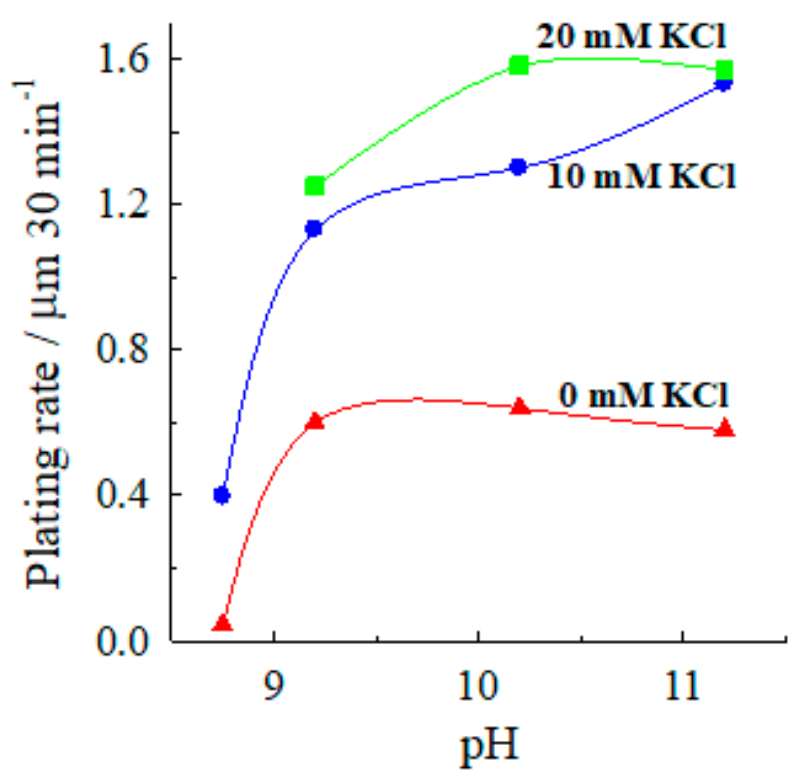

Figure 3. Dependence of the silver deposition rate on the solution $\mathrm{pH}$ at various chloride concentrations. Solution composition (M): $\mathrm{AgNO}_{3}-0.04, \mathrm{CoSO}_{4}-0.10 ;\left(\mathrm{NH}_{3}+\mathrm{NH}_{4}^{+}\right)-4 ; 20{ }^{\circ} \mathrm{C}$. 
The accelerating effect of chloride is also observed in autocatalytic silver deposition solutions with higher ammonia-ammonium $\left(\mathrm{NH}_{3}+\mathrm{NH}_{4}^{+}\right)$salt concentration $7 \mathrm{M}$ at a solution $\mathrm{pH} 11.05$ (Figure 4).



Figure 4. Dependence of the silver deposition rate on the chloride concentration. Solution composition (M): $\mathrm{AgNO}_{3}-0.04, \mathrm{CoSO}_{4}-0.10 ;\left(\mathrm{NH}_{3}+\mathrm{NH}_{4}^{+}\right)-7 ; \mathrm{pH} 11.05 ; 20{ }^{\circ} \mathrm{C}$.

When comparing the results of electroless silver deposition obtained at a temperature of $50{ }^{\circ} \mathrm{C}$ with those for $20^{\circ} \mathrm{C}$, the rate of silver deposition increases with an increase in temperature (Figure 5). At $50{ }^{\circ} \mathrm{C}$, as seen in Figure 5, the rate also increases most strongly with a rise in chloride concentration until ca. $10 \mathrm{mM}$. At upper chloride concentrations, the silver deposition rate changes only a little but is larger than that at $20^{\circ} \mathrm{C}$.

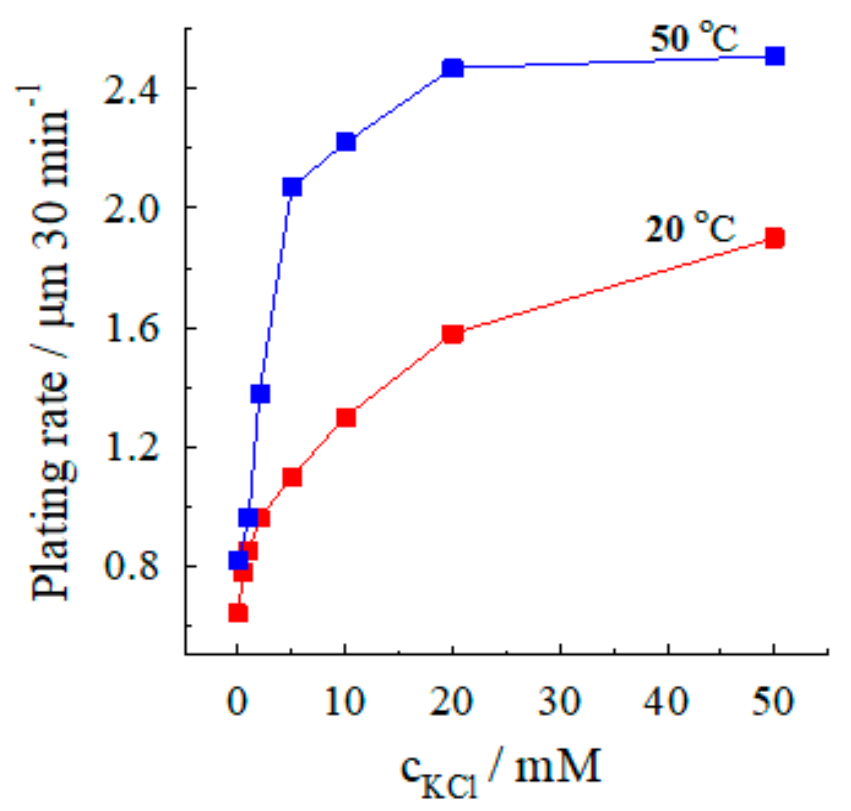

Figure 5. Dependence of the silver deposition rate on chloride concentration at various temperatures. Solution composition $(\mathrm{M})$ : $\mathrm{AgNO}_{3}-0.04, \mathrm{CoSO}_{4}-0.10 ;\left(\mathrm{NH}_{3}+\mathrm{NH}_{4}^{+}\right)-4 ; \mathrm{pH} 10.2$. 


\subsection{Characterization}

The roughness factor $\left(R_{\mathrm{n}}\right)$ of the electroplated silver electrode, which is used as a substrate for electroless plating, is found to be 1.5. When using an electroless plating solution containing $10 \mathrm{mM}$ additive of chloride, the electrolessly deposited silver coating has more developed surface roughness compared with the substrate-the surface roughness factor being 2.

The atomic force microscope (AFM) was used for the silver surface inspection. The typical surface profiles and images are shown in Figure 6. As evident, the surface morphology of silver coatings obtained with a solution containing a chloride additive differs from that obtained without a chloride additive (cf. Figure 6a,b). The dimensions of silver crystallites decrease, and the surface area increases visibly.
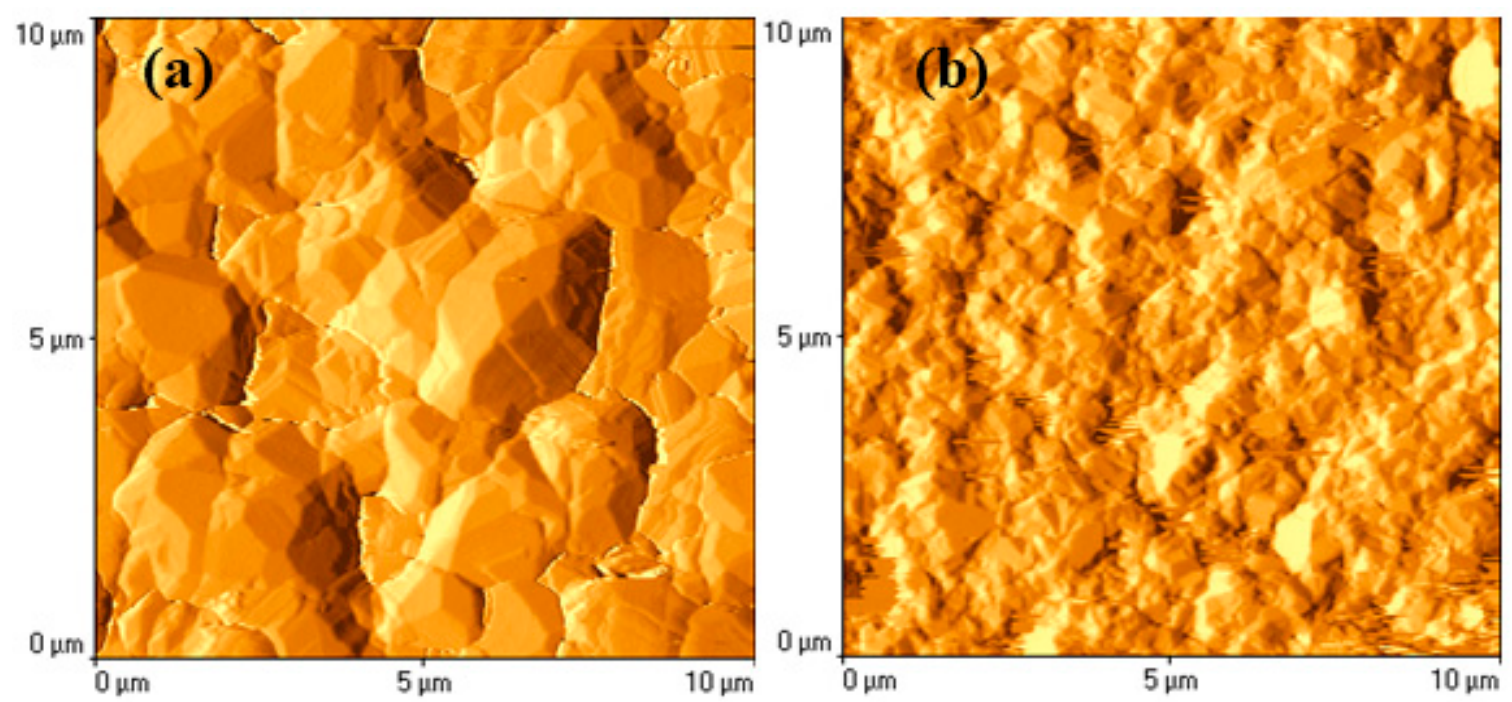

Figure 6. AFM images of silver coatings prepared without $\mathrm{KCl}$ additive (a) and with $100 \mathrm{mM} \mathrm{KCl}$ additive (b).

It is worth to notice that the adhesion of silver coatings is sufficient - the coatings obtained to pass the scotch tape test.

\subsection{EQCM Investigations}

To obtain further information, the effect of chloride ions for electroless silver deposition was investigated in more detail by EQCM. As mentioned before, the autocatalytic Ag(I) reduction by Co(II) in aqueous $\mathrm{NH}_{3}$ solutions (Equation (1)) is the sum of two (cathodic and anodic) partial reactions coinciding on the catalytic surface:

$$
\mathrm{Ag}\left(\mathrm{NH}_{3}\right)_{2}^{+}+\mathrm{e} \rightarrow \mathrm{Ag}+2 \mathrm{NH}_{3}
$$

And

$$
\mathrm{Co}\left(\mathrm{NH}_{3}\right)_{\mathrm{n}}^{2+}+(6-\mathrm{n}) \mathrm{NH}_{3} \rightarrow \mathrm{Co}\left(\mathrm{NH}_{3}\right)_{6}^{3+}+\mathrm{e},(\mathrm{n}=5,6)
$$

Figure 7 shows the dependence of open-circuit potential (a), frequency change rate (b), and change in quartz oscillator frequency (c) for electroless silver deposition from the plating solution containing the both $\mathrm{Ag}(\mathrm{I})$ ions and reducing agent $\mathrm{Co}$ (II) without chloride additive (solid line) and the one containing 1 (dashed line) and $10 \mathrm{mM}$ (dash-dotted line) chloride additives. When the rates of both cathodic (Equation (4)) and anodic (Equation (5)) partial reactions are equal, the silver electrode attains the mixed potential $\left(E_{\mathrm{m}}\right)$ value (Figure $\left.7 \mathrm{a}\right)$. The $E_{\mathrm{m}}$ values are quite stable during the electroless silver deposition and are shifted to more positive potential values with the increase of the chloride concentration (Figure 7a). The autocatalytic silver deposition rate in all cases detected by EQCM is 
constant with time (Figure $7 \mathrm{~b}$ ), indicating a steady-state of the system. In all cases, the quartz crystal frequency decreases, e.g., the coating mass (thickness) increases constantly with time (Figure 7c). Furthermore, the rate of $\mathrm{Ag}(\mathrm{I})$ reduction by $\mathrm{Co}(\mathrm{II})-\mathrm{NH}_{3}$ complexes depends on the concentration of chloride ions and rises with an increase in the chloride concentration up to $10 \mathrm{mM}$ (Figure 7c). The chloride additive of $10 \mathrm{mM}$ enhances the electroless silver deposition rate $(\Delta f)$ about ca. 3.6 times as compared with the additive-free solution (Figure 7c). The inset in Figure 7c shows the mass gain of silver. As evident, ca. $46 \mu \mathrm{g}$ of silver could be obtained after 5 min deposition in the complete $\mathrm{Ag}(\mathrm{I})-\mathrm{Co}(\mathrm{II})-\mathrm{NH}_{3}$ electroless plating solution containing the $10 \mathrm{mM}$ of chloride additive.

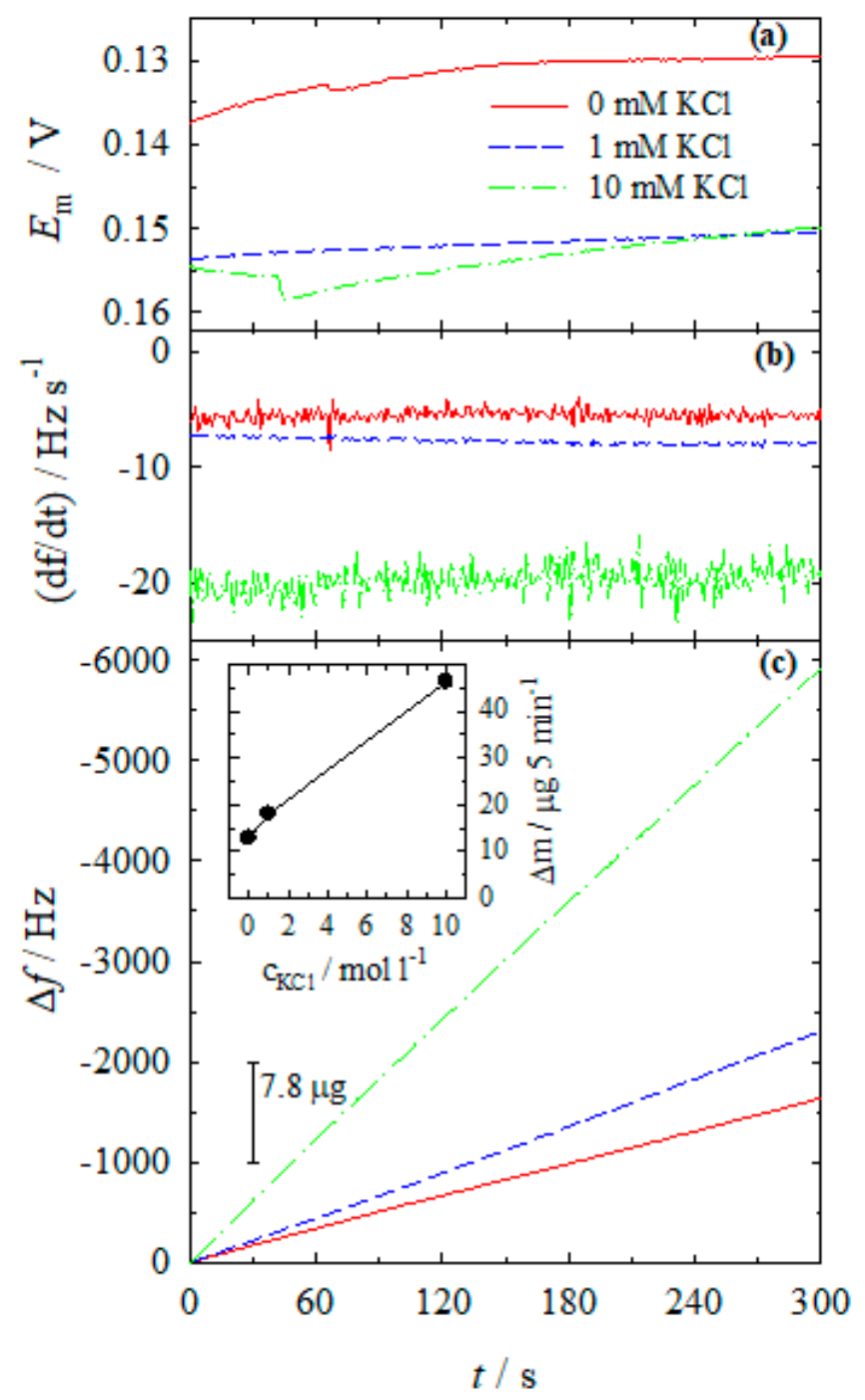

Figure 7. Data on electroless silver deposition on Ag electrode $\left(0.636 \mathrm{~cm}^{2}\right)$ : (a) open-circuit potential, (b) frequency change rate, and (c) change in quartz oscillator frequency. Solution composition (M): $\mathrm{CoSO}_{4}-0.1 ; \mathrm{Ag}_{2} \mathrm{SO}_{4}-5 \times 10^{-3} ; \mathrm{KCl}: 0$ (solid line), $10^{-3}$ (dashed line), $10^{-2}$ (dash-dotted line); $\mathrm{NH}_{3}-4.0 ; \mathrm{pH} 10.9 ; 20^{\circ} \mathrm{C}$. The inset represents the mass gain of silver.

The QCM (quartz crystal microbalance) measurements, in parallel to the CV by determining the mass change, allowed to detect the rate of partial reactions (Ag(I) reduction, Ag dissolution, and $\mathrm{Co}(\mathrm{II})$ oxidation). Figure 8 shows the dependence of the reduction of $\mathrm{Ag}(\mathrm{I})-\mathrm{NH}_{3}$ complexes on chloride ions concentration in the solution containing only $\mathrm{Ag}(\mathrm{I})$ ions. Simultaneous $\mathrm{CV}$ and QCM scans were started to record from the open-circuit potential to the cathodic direction. The stabilized $I-E$ (solid line) and $\mathrm{d} f / \mathrm{d} t-E$ (dashed line) dependencies show their shapes to be identical when the calibration constant of $140 \mathrm{~Hz} \mathrm{~s}^{-1} \mathrm{~mA}^{-1}$ was used (Figure 8). It is seen that in the presence of chloride ions, the reduction of 
$\mathrm{Ag}(\mathrm{I})$ is started at potentials $\sim 0.16-0.17 \mathrm{~V}$, and the limiting currents are reached at $\sim 0.12 \mathrm{~V}$ (Figure $8 \mathrm{~b}, \mathrm{c}$ ), whereas the limiting currents of the reduction of $\mathrm{Ag}(\mathrm{I})$ in the solution without chloride additive are observed at a more negative potential value of $\sim 0.06 \mathrm{~V}$.

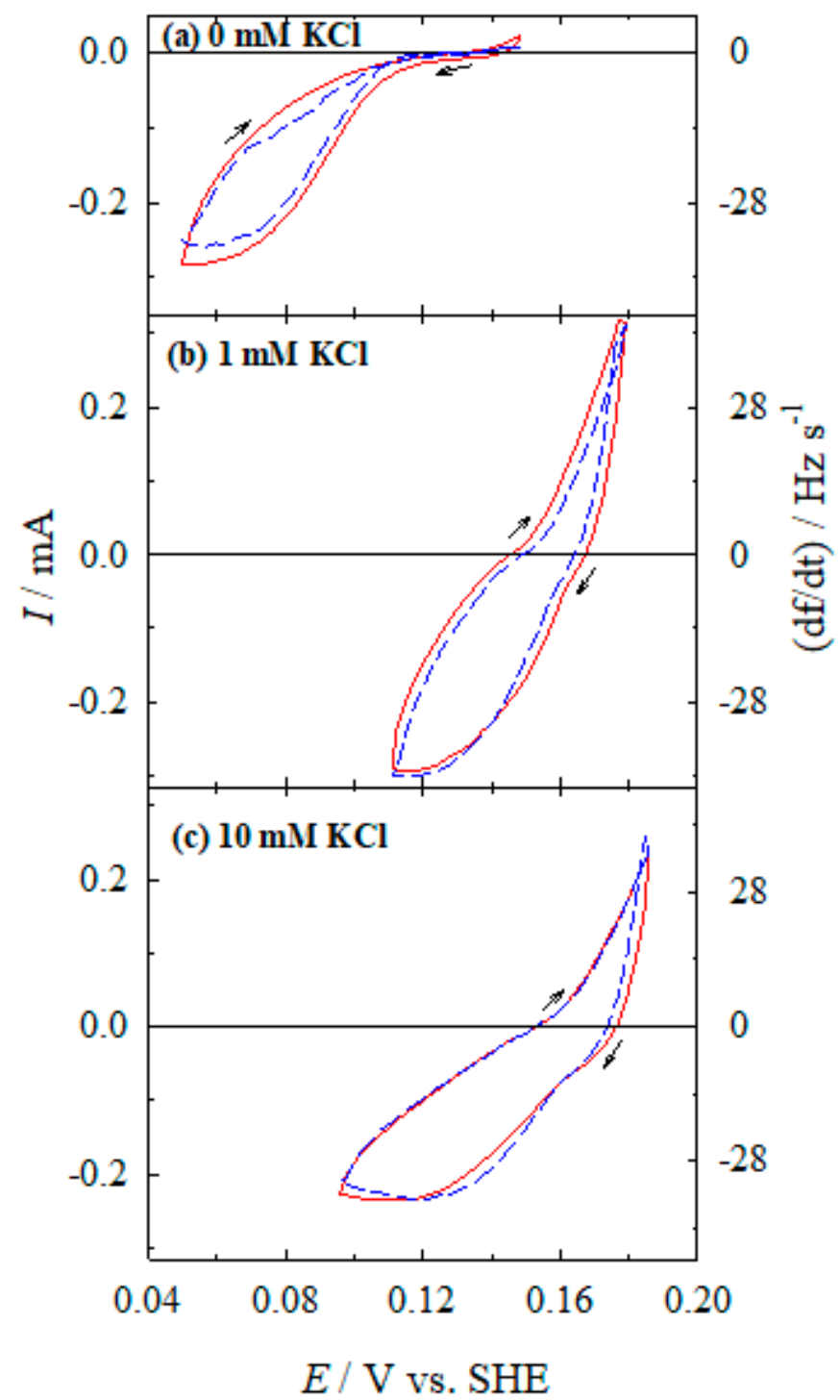

Figure 8. Dependences of the current (solid line) and the frequency change rate (dashed line) on the silver electrode potential. Solution composition (M): $\mathrm{Ag}_{2} \mathrm{SO}_{4}-5 \times 10^{-3} ; \mathrm{NH}_{3}-4.0 ; \mathrm{KCl}: 0$ (a), $10^{-3}$ (b), and $10^{-2}(\mathrm{c}) ; \mathrm{pH} 10.9 ; 20^{\circ} \mathrm{C}$. Potential sweep rate $2 \mathrm{mV} \mathrm{s}^{-1}$.

Figure 9 presents the CVs recorded in the solution containing only Co(II) ions without (a) and with chloride additive of 1 (b), 10 (c), and 100 (d) mM. The insets (b') and (d') show the CVs at an anodic potential limit of $0.1 \mathrm{~V}$. The dashed lines represent the anodic/cathodic Ag current. As evident, in the electrode potential range from -0.25 to $0 \mathrm{~V}$, the calculated silver currents from QCM data is about $0 \mathrm{~mA}$. This indicates that in this potential region, the measured current should be attributed to the $\mathrm{Co}(\mathrm{II}) / \mathrm{Co}(\mathrm{III})$ oxidation/reduction reaction (Figure 9). As evident from the data in Figure 9, the anodic Ag dissolution is detected at potentials more positive than $0 \mathrm{~V}$, e.g., the Ag dissolution occurs simultaneously with the oxidation of $\mathrm{Co}$ (II). Furthermore, the rate of the oxidation of $\mathrm{Co}$ (II) is lower at the potentials more positive than $0 \mathrm{~V}$ of anodic Ag dissolution (Figure 9, the inset b'). 


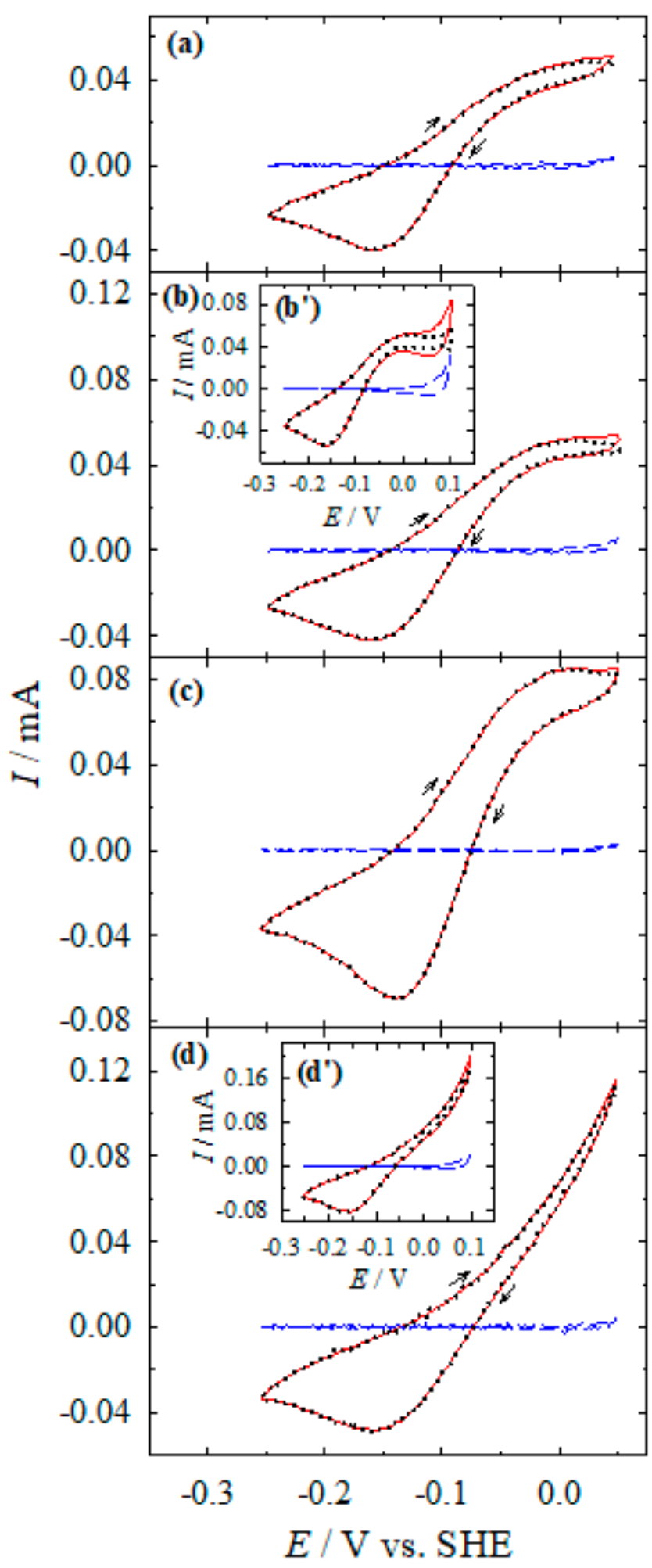

Figure 9. Dependencies of the current (measured directly (solid line), calculated from EQCM data (dashed line), and their difference (dotted line)) on silver electrode potential. Solution composition (M): $\mathrm{CoSO}_{4}-0.1 ; \mathrm{NH}_{3}-4.0 ; \mathrm{KCl}: 0(\mathbf{a}), 10^{-3}(\mathbf{b}), 10^{-2}(\mathbf{c})$, and $10^{-1}(\mathbf{d}) ; \mathrm{pH} 10.9 ; 20^{\circ} \mathrm{C}$. Potential scan rate $2 \mathrm{mV} \mathrm{s}^{-1}$. The insets $\left(\mathbf{b}^{\prime}\right)$ and $\left(\mathbf{d}^{\prime}\right)$ represent the cyclic voltammograms (CVs) at the anodic potential limit of $0.1 \mathrm{~V}$.

It should be noted that the process of $\mathrm{Co}(\mathrm{II})$ anodic oxidation on the Ag electrode is enhanced when chloride ions are presenting in solution. At $1 \mathrm{mM}$ level up to $10 \mathrm{mM}, \mathrm{KCl}$ additive increases 
the rate of $\mathrm{Co}(\mathrm{II})$ oxidation only narrowly, while at $100 \mathrm{mM}, \mathrm{KCl}$ increases the rate considerably (Figure 9). The $100 \mathrm{mM} \mathrm{KCl}$ additive increases the Co(II) oxidation rate about four-fold. Acceleration of $\mathrm{Co}(\mathrm{II})-\mathrm{NH}_{3}$ complexes oxidation in the presence of chloride is related to the adsorption of chloride ions on the silver surface, which are, possibly, involved in the oxidation of Co(II) and mediate the electron transfer. The enhancing effect of halide ions is observed during the oxidation of Co(II)-En complex on the copper electrode [20,22]. It has been shown that halide ions facilitate the electrons transfer through the halide bridge. The importance of halide-containing complexes in a bridged electron transfer occurring in the homogeneous redox reactions of the $\mathrm{Co}(\mathrm{III}) / \mathrm{Co}(\mathrm{II})$ couple is known [24].

$\mathrm{CV}$ and QCM measurements in the complete electroless plating solution, containing both reducing agent ( $\mathrm{Co}(\mathrm{II})-\mathrm{NH}_{3}$ complex) and metal ions to be reduced ( $\mathrm{Ag}(\mathrm{I})-\mathrm{NH}_{3}$ complex) in the presence of chloride ions, show more complicated electrochemical behavior (Figure 10) compared with the data obtained in $\mathrm{Ag}(\mathrm{I})-\mathrm{NH}_{3}$ (Figure 8) or $\mathrm{Co}(\mathrm{II})-\mathrm{NH}_{3}$ (Figure 9) solutions.

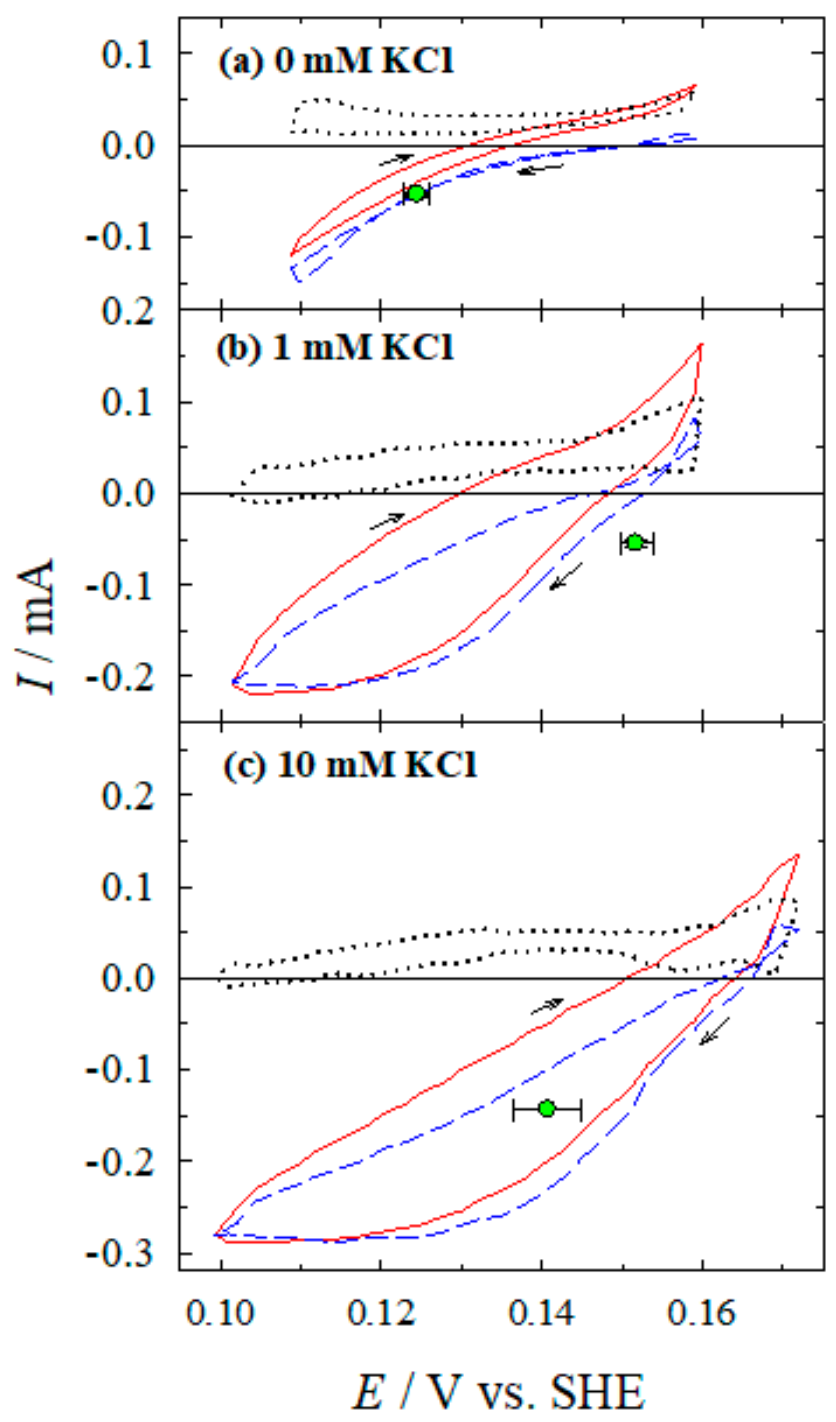

Figure 10. Dependences of the current (measured directly (solid line), calculated from EQCM data (dashed line), and their difference (dotted line)) on silver electrode potential in stationary solution. Solution composition (M): $\mathrm{Ag}_{2} \mathrm{SO}_{4}-5 \times 10^{-3} ; \mathrm{CoSO}_{4}-0.1 ; \mathrm{NH}_{3}-4.0 ; \mathrm{KCl}: 0$ (a), $10^{-3}$ (b), and $10^{-2}$ (c); $\mathrm{pH} 10.9 ; 20{ }^{\circ} \mathrm{C}$. Potential sweep rate $2 \mathrm{mV} \mathrm{s}^{-1}$. - - the rate of silver deposition under open-circuit conditions.

This would be expected for the situation when anodic and cathodic processes are coinciding on the same metal surface at the same potentials. The current measured corresponds to the algebraic 
sum of anodic $\mathrm{Co}(\mathrm{II})$ oxidation (and Ag dissolution at potentials positive enough) and cathodic $\mathrm{Ag}(\mathrm{I})$ reduction currents. The cathodic silver deposition (or silver dissolution) rate is obtained from EQCM data. The current of the anodic partial process of $\mathrm{Co}(\mathrm{II})$ oxidation is found from the difference between the current measured by $\mathrm{CV}$ and a partial current of cathodic reduction of $\mathrm{Ag}(\mathrm{I})$, or anodic dissolution of Ag calculated from the quartz crystal frequency change rate.

Thus, such partial currents of $\mathrm{Ag}(\mathrm{I})$ reduction and $\mathrm{Co}(\mathrm{II})$ oxidation can be compared with those measured in separate $\mathrm{Ag} / \mathrm{Ag}(\mathrm{I})-\mathrm{NH}_{3}$ (Figure 8 ) and $\mathrm{Ag} / \mathrm{Co}(\mathrm{II})-\mathrm{NH}_{3}$ (Figure 9) systems. Figure 11 shows the comparison of the $\mathrm{Ag}$ partial reactions measured in an $\mathrm{Ag} / \mathrm{Ag}(\mathrm{I})-\mathrm{NH}_{3}$ system without $\mathrm{Co}$ (II) from Figure 8 and that obtained in the complete $\mathrm{Ag} / \mathrm{Ag}(\mathrm{I})-\mathrm{Co}(\mathrm{II})-\mathrm{NH}_{3}$ system from Figure 10. As illustrated in Figure 10 and evident from Figure 11, the rate of the cathodic partial process in the presence of $\mathrm{Co}(\mathrm{II})$ is similar, in general, to that observed in a separate $\mathrm{Ag} / \mathrm{Ag}(\mathrm{I})-\mathrm{NH}_{3}$ system. At chloride concentrations of 1 to $10 \mathrm{mM}$, limiting currents are observed at more positive potential values $(<0.12 \mathrm{~V})$ (cf. Figure $10 \mathrm{~b}, \mathrm{c}$ and Figure $11 \mathrm{~b}, \mathrm{c}$ ) as compared with that in the additive-free solution (Figures 10a and 11a). In the case of the electroless silver deposition solution without chloride ions, limiting current is not reached yet at these potentials.

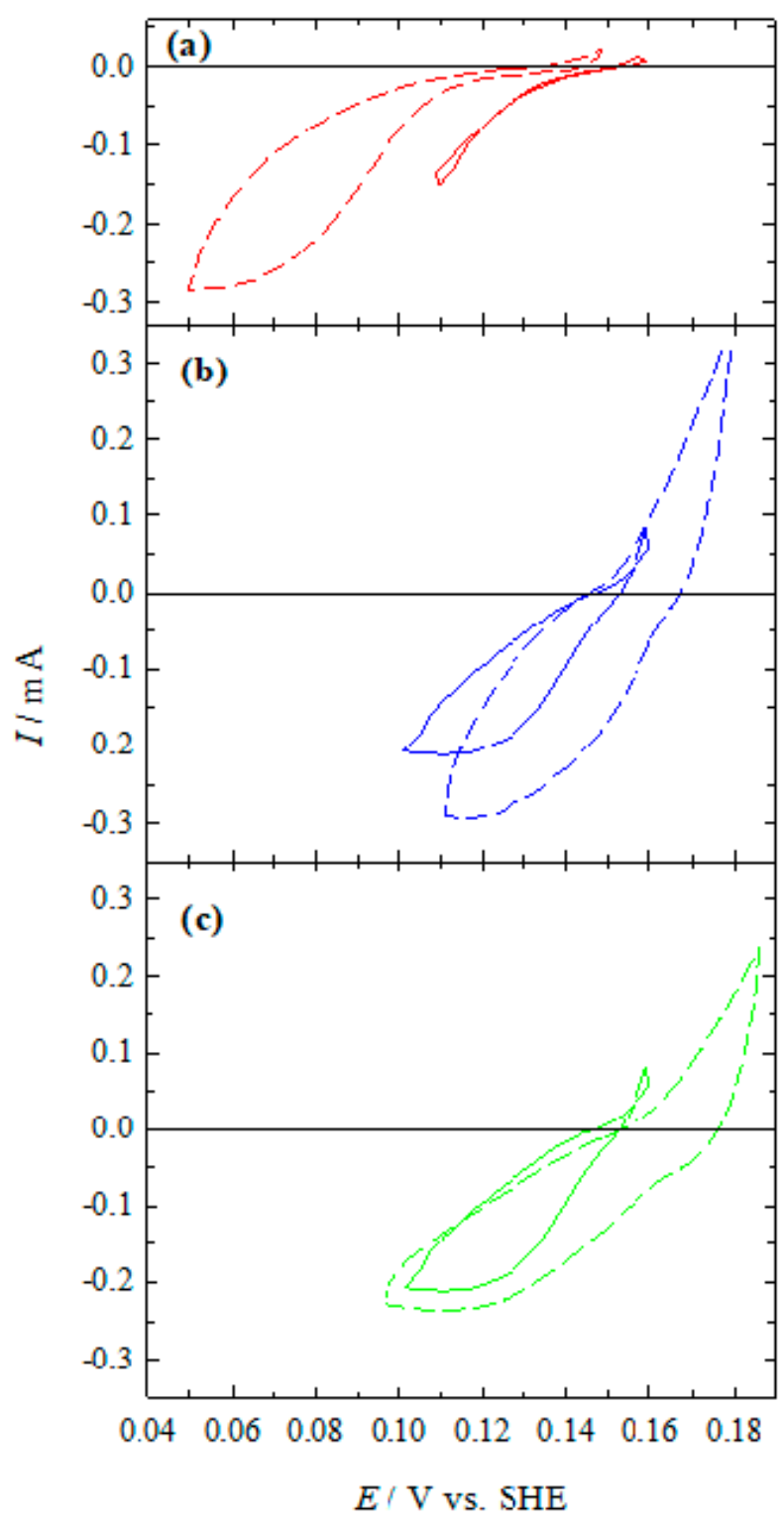

Figure 11. Currents for Ag deposition/dissolution are the same as in Figure 8 (dashed lines) and Figure 10 (solid lines). $\mathrm{KCl}: 0(\mathbf{a}), 10^{-3}(\mathbf{b})$, and $10^{-2}(\mathbf{c}) ; \mathrm{pH} 10.9 ; 20^{\circ} \mathrm{C}$. Potential sweep rate $2 \mathrm{mV} \mathrm{s}^{-1}$. 
The comparison of $\mathrm{Co}(\mathrm{II})$ oxidation and $\mathrm{Co}(\mathrm{III})$ reduction currents in the presence of $\mathrm{Ag}(\mathrm{I})$ (Figure 10) with those in a separate $\mathrm{Ag} / \mathrm{Co}(\mathrm{II})-\mathrm{NH}_{3}$ system (Figure 9) shows that in the presence of $\mathrm{Ag}(\mathrm{I})$, the $\mathrm{Co}(\mathrm{II})$ oxidation current has similar value as in the absence of $\mathrm{Ag}(\mathrm{I})$.

Chloride ions play an important role in the enhancement of the rate of electroless silver deposition, and its effect is observed in both anodic Co(II) oxidation and cathodic Ag(I) reduction partial reactions and could be explained by the formation of halide bridges.

\section{Conclusions}

In a study of an electroless silver deposition system with a reducing agent $\mathrm{Co}(\mathrm{II})$-ammonia complexes, it was found that the addition of chlorides accelerates the overall process of electroless silver deposition. The addition of $10 \mathrm{mM}$ chloride leads to an acceleration of electroless silver deposition by a factor of 2-2.5, and at higher chloride concentrations $(40-50 \mathrm{mM})$, a three-fold acceleration is achieved.

The data of EQCM measurements confirm that the accelerating effect of chloride ions is attributed to the enhancement of both partial electrochemical reactions-mainly the anodic oxidation of Co(II) and, to a lesser extent, the cathodic reduction of $\mathrm{Ag}(\mathrm{I})$. It has been determined that the presence of chloride ions increases the anodic oxidation of $\mathrm{Co}$ (II)- $\mathrm{NH}_{3}$ complex, e.g., the $100 \mathrm{mM} \mathrm{KCl}$ additive increases the rate of $\mathrm{Co}(\mathrm{II})-\mathrm{NH}_{3}$ complex oxidation about four-fold. The effect of chloride ions may be related to the adsorption of chloride ions on the silver surface and the formation of chloride bridges, which mediate the electron transfer.

Author Contributions: This study was conducted through the contributions of all authors. Conceptualization L.T.-T. and E.N.; Methodology, A.J. and I.S.; Investigation, L.T.-T., A.J., and I.S.; Writing-Original Draft Preparation, L.T.-T.; Writing-Review and Editing, E.N., G.R., and K.R; Visualization, G.R. and K.R. All authors have read and agreed to the published version of the manuscript.

Funding: This work was supported by the European Regional Development Fund (project No 01.2.2-LMT-K-718-01-0004) under a grant agreement with the Research Council of Lithuania (LMTLT).

Conflicts of Interest: The authors declare no conflict of interest.

\section{References}

1. Mallory, G.O.; Hajdu, J.B. (Eds.) Electroless Plating: Fundamentals and Applications; American Electroplaters and Surface Finishers Society: Orlando, FL, USA, 1990.

2. Vaškelis, A. Coatings Technology Handbook, 2nd ed.; Satas, D., Tracton, A.A., Eds.; Marcel Dekker: New York, NY, USA, 2001; p. 213.

3. Pearlstein, F.; Weightman, R.F. Electroless silver deposition. Plating 1971, 58, 1014.

4. Vaškelis, A.; Diemontaite,, O. Cheminio sidabravimo tirpalai. 1. Ag (I) redukcija cianidu tirpaluose. Lietuvos TSR MA Darbai. B Ser. 1975, 4, 23-30.

5. Koura, N.; Kubota, A. Electroless plating of silver. J. Met. Fin. Soc. Jpn. 1985, 36, 182-190. [CrossRef]

6. Vaškelis, A.; Diemontaitè, O. Cheminio sidabravimo tirpalai. 5. Ag (I) redukcija Cu (I), Fe (II), Co (II) jonais. Lietuvos TSR MA Darbai. B Ser. 1980, 1, 3-10.

7. Vaškelis, A.; Norkus, H.J.; Rozovskis, G.; Vinkevičius, H.J. New methods of electroless plating and direct electroplating of plastics. Trans. IMF 1997, 75, 1-3. [CrossRef]

8. Vaškelis, A.; Norkus, E.; Jagminienè, A.; Tamašauskaitė-Tamašiūnaitè, L. Electroless silver plating at elevated temperature using cobalt(II)-ammonia complex compounds as reducing agents. Chemija 1998, N2, $105-108$.

9. Vaškelis, A.; Norkus, E.; Reklaitis, J.; Jagminienè, A.; Tamašauskaitè-Tamašiūnaitè, L. Electroless silver plating using cobalt(II)-ammonia complex compounds as reducing agents. 1 . The thermodynamical aspects. Chemija 1998, N4, 265-271.

10. Norkus, E.; Vaškelis, A.; Jagminienè, A.; Tamašauskaitè-Tamašiūnaitè, L. Electroless silver plating using cobalt(II)-ammonia complex compounds as reducing agents. 2. A kinetic study. Chemija 1998, N4, $272-277$.

11. Vaškelis, A.; Norkus, E. Autocatalytic processes of copper(II) and silver(I) reduction by cobalt(II) complexes. Electrochim. Acta 1999, 44, 3667-3677. [CrossRef] 
12. Vaškelis, A.; Norkus, E.; Jagminienè, A.; Tamašauskaitė-Tamašiūnaitè, L. Stromlose Versilberung mit Kobalt(II)-Ammoniak-Komplexverbindungen als Reduktionsmittel. Thermodynamishe Aspekte und kinetische Untersuchungen. Teil 1. Galvanotechnik 2000, 91, 2129-2135.

13. Vaškelis, A.; Norkus, E.; Jagminienè, A.; Tamašauskaitė-Tamašiūnaitè, L. Stromlose Versilberung mit Kobalt(II)-Ammoniak-Komplexverbindungen als Reduktionsmittel. Thermodynamishe Aspekte und kinetische Untersuchungen. Teil 2. Galvanotechnik 2000, 91, 3395-3404.

14. Norkus, E.; Vaškelis, A.; Jagminienè, A.; Tamašauskaitè-Tamašiūnaitè, L. Kinetics of electroless silver deposition using cobalt(II)-ammonia complex compounds as reducing agents. J. Appl. Electrochem. 2001, 31, 1061-1066. [CrossRef]

15. Vaškelis, A.; Jagminienè, A.; Juškènas, R.; Matulionis, E.; Norkus, E. Structure of electroless silver coatings obtained using cobalt(II) as reducing agent. Surf. Coat. Technol. 1996, 82, 165-168. [CrossRef]

16. Vaškelis, A.; Jagminienè, A. Cheminiu būdu nusodintų sidabro dangu korozinis atsparumas ir apsauginè geba. Zaščita Metalov. 1989, 25, 305-308.

17. Hagiwara, K.; Kawasaki, J.; Ohgane, M.; Tomari, Y.; Honma, H. Investigation of life extension and optical application for electroless plating using Co (II) complex ions as a reducing Agent. J. Surf. Fin. Soc. Jpn. 2001, 52, 778-782. [CrossRef]

18. Vaškelis, A.; Jačiauskienè, J.; Jagminienè, A.; Norkus, E. Obtaining of IB group metal films by novel electroless deposition method. Solid State Sci. 2002, 4, 1299-1304. [CrossRef]

19. Vaškelis, A.; Jagminienè, A.; Tamašauskaitè-Tamašiūnaitè, L. Cobalt(II) anodic oxidation on silver in ammonia and ethylenediamine solutions studied by rotating disc electrode and EQCM techniques. J. Electroanal. Chem. 2002, 521, 137-143. [CrossRef]

20. Vaškelis, A.; Stalnionis, G.; Jusys, Z. Cyclic voltammetry and quartz crystal microgravimetry study of autocatalytic copper(II) reduction by cobalt(II) in ethylenediamine solutions. J. Electroanal. Chem. 1999, 465, 142-152. [CrossRef]

21. Vashkyalis, A.; Demontaite, O. Determination of the surface-area of silver by electrochemical deposition of a lead monolayer. Sov. Electrochem. 1978, 14, 1050-1052.

22. Jusys, Z.; Stalnionis, G. Wall-jet electrochemical quartz crystal microgravimetry: Oxidation of Co(II)-ethylenediamine complexes on copper electrode. Electrochim. Acta 2000, 45, 3675-3682. [CrossRef]

23. Sauerbrey, G.Z. The use of quarts oscillators for weighing thin layers and for microweighing. Z. Phys. 1959, 155, 206-222. [CrossRef]

24. Cannon, R.D. Electron Transfer Reactions; Butterworth: London, UK, 1980.

Publisher's Note: MDPI stays neutral with regard to jurisdictional claims in published maps and institutional affiliations.

(C) 2020 by the authors. Licensee MDPI, Basel, Switzerland. This article is an open access article distributed under the terms and conditions of the Creative Commons Attribution (CC BY) license (http://creativecommons.org/licenses/by/4.0/). 